\section{TRENDS IN WORLD MILITARY EXPENDITURE, 2013}

\author{
SAM PERLO-FREEMAN AND CARINA SOLMIRANO
}

Global military expenditure fell in 2013, by 1.9 per cent in real terms, to reach $\$ 1747$ billion. This was the second consecutive year in which spending fell, and the rate of decrease was higher than the 0.4 per cent fall in 2012 (see figure 1).

A pattern has been established in recent years whereby military spending has fallen in the West-that is, in North America, Western and Central Europe, and Oceania-while it has increased in other regions. This tendency was even more pronounced in 2013, with military spending increasing in every region and subregion outside the West. In fact, the total for the world excluding just one country-the United States-increased by 1.8 per cent in 2013, despite falls in Europe and elsewhere.

From 14 April 2014 the SIPRI Military Expenditure Database includes newly released information on military expenditure in 2013. This Fact Sheet describes the global, regional and national trends in military expenditure that are revealed by the new data, with a special focus on those countries that have more than doubled their military spending over the period 2004-13.

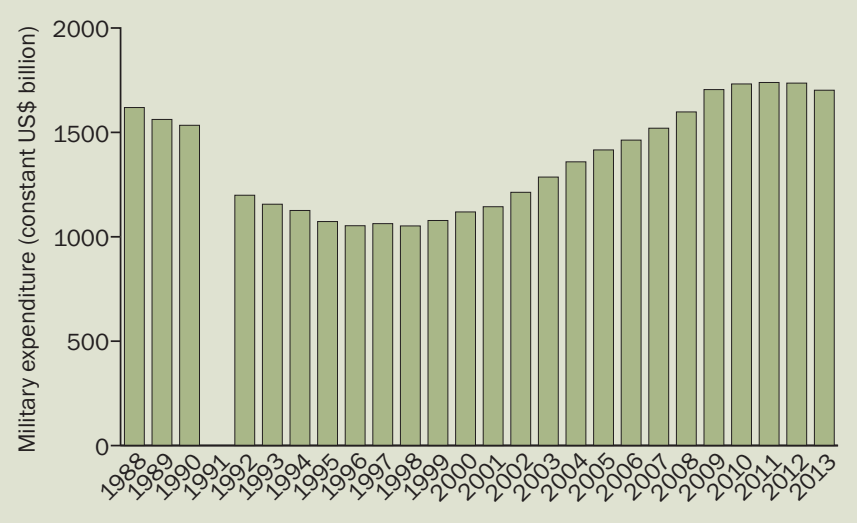

Figure 1. World military expenditure, 1988-2013

Note: The totals are based on the data on 172 states in the SIPRI Military Expenditure Database, <http://www.sipri.org/databases/milex/>. The absence of data for the Soviet Union in 1991 means that no total can be calculated for that year.

\section{KEY FACTS}

- Global military expenditure was $\$ 1747$ billion in 2013.

- Total spending fell by 1.9 per cent in real terms between 2012 and 2013. This was the second consecutive year in which spending fell.

- Military spending fell in the West-North America, Western and Central Europe, and Oceania-while it increased in all other regions.

- The five biggest spenders in 2013 were the United States, China, Russia, Saudi Arabia and France.

- Military spending by the USA fell by 7.8 per cent, to $\$ 640$ billion. A large part of the fall can be attributed to the reduction in spending on overseas military operations.

- China's spending increased by 7.4 per cent, representing a long-term policy of rising military spending in line with economic growth.

- Russia's military spending increased by 4.8 per cent, and for the first time since 2003 it spent a bigger share of its GDP on the military than the USA.

- Saudi Arabia was the fourth biggest spender in 2013, having ranked seventh in 2012. The United Kingdom has now fallen to sixth place.

- A total of 23 countries doubled their military spending in real terms between 2004 and 2013. These countries are in all regions of the world apart from North America, Western and Central Europe, and Oceania. 
Table 1. The 15 countries with the highest military expenditure in 2013 Spending figures are in US\$, at current prices and exchange rates. Figures for changes are calculated from spending figures in constant (2012) prices.

\begin{tabular}{|c|c|c|c|c|c|c|}
\hline \multicolumn{2}{|c|}{ Rank } & \multirow[b]{2}{*}{ Country } & \multirow{2}{*}{$\begin{array}{l}\text { Spending, } \\
2013 \text { (\$ b.) }\end{array}$} & \multirow{2}{*}{$\begin{array}{l}\text { Change, } \\
2004-13 \\
(\%)\end{array}$} & \multicolumn{2}{|c|}{$\begin{array}{l}\text { Spending as a } \\
\text { share of GDP (\%) }\end{array}$} \\
\hline 2013 & 2012 & & & & 2013 & 2004 \\
\hline 1 & 1 & USA & 640 & 12 & 3.8 & 3.9 \\
\hline 2 & 2 & China & {$[188]$} & 170 & [2.0] & {$[2.1]$} \\
\hline 3 & 3 & Russia & {$[87.8]$} & 108 & {$[4.1]$} & [3.5] \\
\hline 4 & 7 & Saudi Arabia & 67.0 & 118 & 9.3 & 8.1 \\
\hline 5 & 4 & France & 61.2 & -6.4 & 2.2 & 2.6 \\
\hline 6 & 6 & $\mathrm{UK}$ & 57.9 & -2.5 & 2.3 & 2.4 \\
\hline 7 & 9 & Germany & 48.8 & 3.8 & 1.4 & 1.4 \\
\hline 8 & 5 & Japan & 48.6 & -0.2 & 1.0 & 1.0 \\
\hline 9 & 8 & India & 47.4 & 45 & 2.5 & 2.8 \\
\hline 10 & 12 & South Korea & 33.9 & 42 & 2.8 & 2.5 \\
\hline 11 & 11 & Italy & 32.7 & -26 & 1.6 & 2.0 \\
\hline 12 & 10 & Brazil & 31.5 & 48 & 1.4 & 1.5 \\
\hline 13 & 13 & Australia & 24.0 & 19 & 1.6 & 1.8 \\
\hline 14 & 16 & Turkey & 19.1 & 13 & 2.3 & 2.8 \\
\hline 15 & 15 & $\mathrm{UAE}^{b}$ & [19.0] & 85 & 4.7 & 4.7 \\
\hline \multicolumn{2}{|c|}{ Total top 15} & & 1408 & & & \\
\hline \multicolumn{2}{|c|}{ World total } & & 1747 & 26 & 2.4 & 2.4 \\
\hline
\end{tabular}

[] = SIPRI estimate.

${ }^{a}$ The figures for military expenditure as a share of gross domestic product (GDP) are based on data from the International Monetary Fund (IMF) World Economic Outlook database, Oct. 2013.

${ }^{b}$ Data for the United Arab Emirates (UAE) is for 2012, as figures for 2013 are not available.

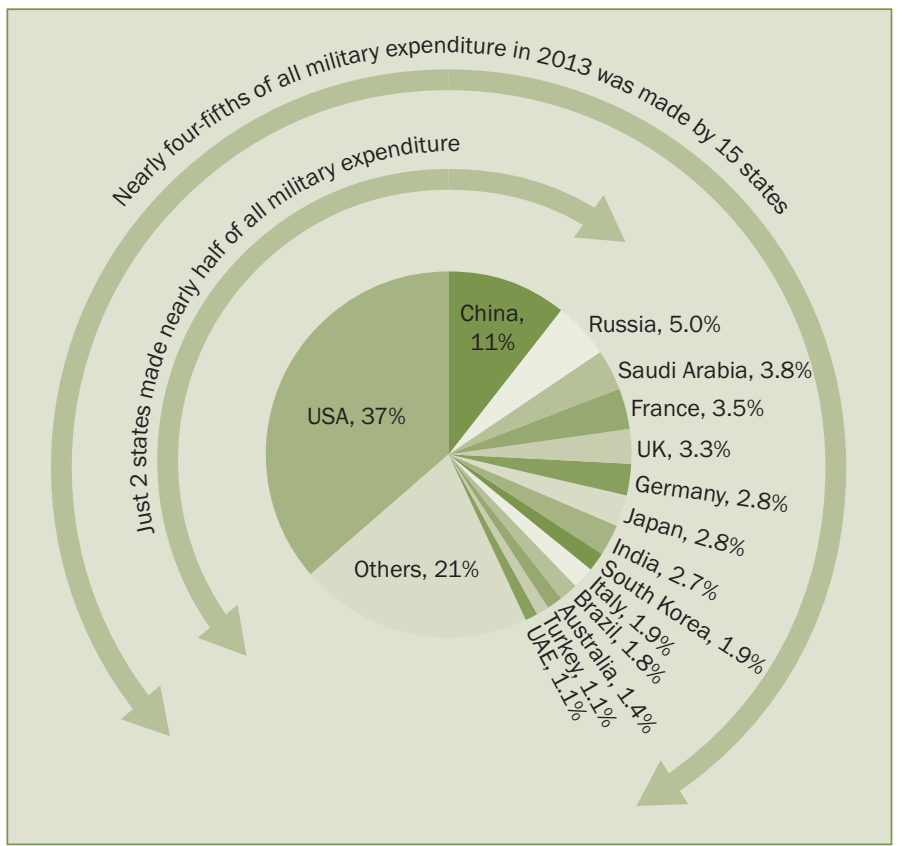

Figure 2. The share of world military expenditure of the 15 states with the highest expenditure in 2013

\section{THE TOP 15 MILITARY SPENDERS IN 2013}

There was only one change in the list of countries comprising the world's top 15 military spenders in 2013, with Canada dropping out, to be replaced by Turkey (see table 1). There were also several changes in order. Most notably, Saudi Arabia climbed from seventh to fourth place, having increased its military spending by 14 per cent in 2013. Among the largest spenders, Saudi Arabia has by far the highest military burden-that is, military spending as a share of GDP. At 9.3 per cent, it is also the second highest (after Oman) for any country for which SIPRI has recent data. Along with Saudi Arabia's rise, the United Kingdom has fallen out of the top 5 spenders, although revised figures for 2011 and 2012 show that the UK had already fallen to sixth place then, probably for the first time since World War II.

Military spending by the USA declined by 7.8 per cent in real terms in 2013, to $\$ 640$ billion. A part of the fall ( $\$ 20$ billion of the $\$ 44$ billion nominal fall) can be attributed to the reduction in outlays for Overseas Contingency Operations (OCO)that is, overseas military operations, chiefly in Afghanistan and Iraq.

China's spending increased by 7.4 per cent in real terms. While China has been behaving more assertively in recent years in territorial disputes with Japan in the East China Sea, and with the Philippines and Viet Nam in the South China Sea, these heightened tensions do not seem to have changed the trend in Chinese military spending, which represents a long-term policy of rising military spending in line with economic growth.

Russia's spending increased by 4.8 per cent in real terms, and its military burden exceeded that of the USA for the first time since 2003. Russia's spending has risen as it continues to implement the State Armaments Plan for 2011-20, under which it plans to spend 20.7 trillion roubles ( $\$ 705$ billion) on new and upgraded armaments. The goal is to replace 70 per cent of equipment with 'modern' weapons by 2020.

While South Korea and Turkey also increased their spending, military spending fell in France, the 
UK, Italy, Brazil, Australia and Canada, as well as the USA. Spending by Germany, Japan and India was essentially unchanged. For much of the 2000s, military spending increased fairly rapidly in Brazil and India (as it did in fellow 'BRIC' countries Russia and China). However, since 2009-10 these increases have stopped or gone slightly into reverse, as economic growth has weakened and spending on other sectors has taken priority.

\section{REGIONAL TRENDS}

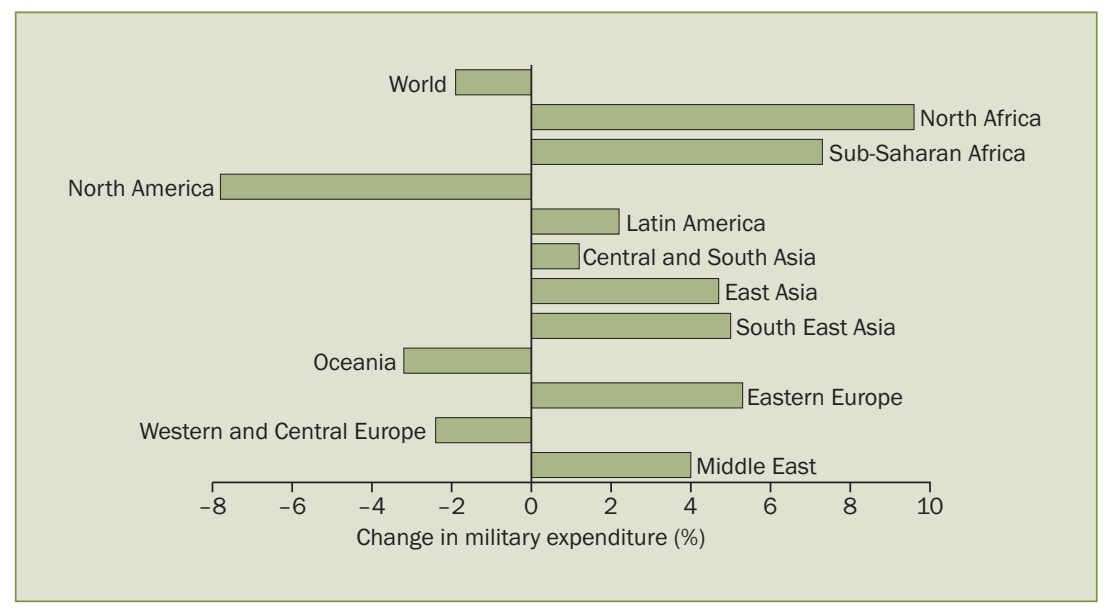

Figure 3. Changes in military expenditure, by region, 2012-13

While spending in North America and Western and Central Europe fell in 2013 , it increased in all other regions (see figure 3). The largest increase was in Africa, by 8.3 per cent.

\section{Western and Central Europe}

In Western and Central Europe, a majority of countries continued to cut military spending as austerity policies were maintained in most of the region. The falls in the region since the beginning of the financial and economic crisis in 2008 are no longer confined to Central Europe and the 'crisis' countries of Western Europe (see table 2). Falls of over 10 per cent in real terms since 2008 have now been recorded in Austria, Belgium, Greece, Ireland, Italy, the Netherlands, Spain and the UK, as well as all countries in Central Europe except Poland. In contrast, Germany's military spending was 2 per cent higher.

France, despite continuing weak economic growth, has largely maintained its military spending during the global economic crisis, and spending in 2013 was just 4 per cent lower than in 2008. This trend is likely to continue, following the adoption in 2013 of the Military Programming Law for the period 2014-19. The law sets the total defence budget, excluding military pensions, at $€ 190$ billion ( $\$ 252$ billion) over 6 years (at 2013 prices). The budgets for $2014-16$ are planned to be $€ 31.4$ billion ( $\$ 41.7$ billion) each year in current prices, implying a slight fall in real terms. Long-term plans for the period to 2025 laid out in the April 2013 Defence and Security White Paper suggest a subsequent stabilization in

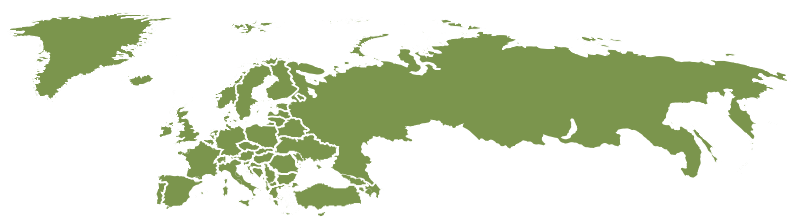

Table 2. Military expenditure in Europe

\begin{tabular}{lclc} 
& \multirow{2}{*}{ Spending, } & \multicolumn{2}{l}{ Change $(\%)$} \\
\cline { 3 - 4 } & $2013(\$ \mathrm{~b})$. & $2012-13$ & $2004-13$ \\
\hline Europe & 410 & -0.7 & 7.6 \\
Eastern Europe & 98.5 & 5.3 & 112 \\
Western and & 312 & -2.4 & -6.5 \\
$\quad$ Central Europe & & & \\
\hline
\end{tabular}

Major changes, 2012-13

\begin{tabular}{lcll}
\hline Major increases & $\%$ & Major decreases & $\%$ \\
\hline Ukraine & 16 & Spain & -13 \\
Belarus & 15 & Albania & -13 \\
Latvia & 9.3 & Hungary & -12 \\
Switzerland & 9.0 & Netherlands & -8.3 \\
\hline
\end{tabular}
real terms.

\section{Latin America}

Military expenditure in Latin America increased by 2.2 per cent in real terms in 2013 and by 61 per cent between 2004 and 2013 (see table 3). In contrast to previous years, the rate of increase of military spending in South 
Table 3. Military expenditure in the Americas

\begin{tabular}{lclll} 
& & \multicolumn{2}{l}{ Spending, } & \multicolumn{2}{l}{ Change (\%) } \\
\cline { 3 - 4 } & $2013(\$ \mathrm{~b})$. & $2012-13$ & $2004-13$ \\
\hline Americas & 736 & -6.8 & 16 \\
Central America & 9.6 & 6.0 & 94 \\
$\quad \begin{array}{lll}\text { and Caribbean } \\
\text { North America }\end{array}$ & 657 & -7.8 & 12 \\
South America & 67.4 & 1.6 & 58 \\
\hline
\end{tabular}

Major changes, 2012-13

\begin{tabular}{llll}
\hline Major increases & $\%$ & Major decreases & $\%$ \\
\hline Paraguay & 33 & Jamaica & -9.0 \\
Honduras & 22 & United States & -7.8 \\
Nicaragua & 18 & El Salvador & -4.5 \\
Colombia & 13 & Brazil & -3.9 \\
\hline
\end{tabular}

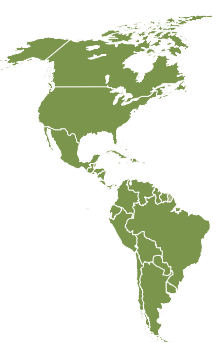

America has slowed down, primarily due to Brazil, the largest spender in the region, decreasing military spending by 3.9 per cent in 2013. Brazilian military spending had been increasing rapidly, by over 7 per cent per year between 2003 and 2010, but it peaked in 2010.

In Central America and the Caribbean, military spending continued to grow rapidly, especially in Honduras (22 per cent), Nicaragua (18 per cent) and Guatemala (11 per cent), in the wake of continuing drug cartel-related violence. Mexico also increased spending by 5.1 per cent, despite weaker economic growth.

\section{Africa}

Africa had the largest relative rise in military spending in 2013 of any region, by 8.3 per cent, to reach $\$ 44.9$ billion (see table 4). While the regional trend tends to be dominated by a few key countries, military spending rose in two-thirds of the countries for which data is available.

Ghana more than doubled its military spending in 2013, from \$109 million in 2012 to $\$ 306$ million in 2013. This does not include funds from donors, which totalled $\$ 47$ million in 2013. According to the budget statement, the budget will allow continued modernization of the armed forces, which are heavily involved in international peacekeeping operations.

Table 4. Military expenditure in Africa

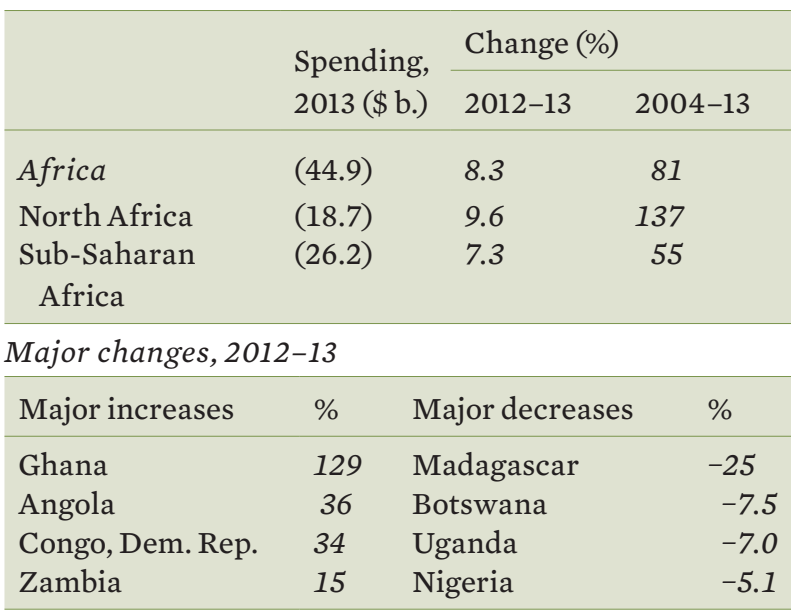

()$=$ uncertain estimate.

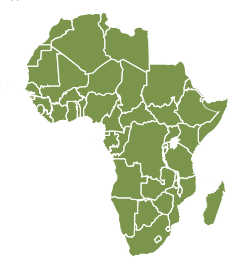

Despite the huge increase, Ghana's military burden in 2013 is projected to be only 0.6 per cent of GDP.

Algeria continued the breakneck pace of growth in its military spending, with an 8.8 per cent increase in 2013 , to reach $\$ 10.4$ billion-the first time an African country has spent more than $\$ 10$ billion on its military. The reasons for Algeria's ongoing militarization include its desire for regional power status, the powerful role of the military, the threat of terrorism-including from armed Islamist groups in neighbouring Mali-and the ready availability of oil funds.

Another country where oil wealth is supporting increased military spending is Angola, which became the second largest military spender in Africa-and the largest in subSaharan Africa-in 2013, with an increase of 36 per cent in 2013 (and 175 per cent since 2004), to reach $\$ 6.1$ billion. This is the first time that Angola's spending has surpassed that of South Africa, which spent $\$ 4.1$ billion in 2013, an increase of 17 per cent since 2004. Angola and Algeria both now have military burdens of 4.8 per cent of GDP, the highest in Africa for countries where recent data is available.

\section{Asia and Oceania}

Military expenditure in Asia and Oceania increased by 3.6 per cent in 2013, to reach $\$ 407$ billion. Asia and Oceania is the only region where spending has 
increased in every year since the beginning of the current consistent series of SIPRI data in 1988.

Most of the increase in the region in 2013 was due to a 7.4 per cent increase by China; excluding China, spending in the rest of the region increased by just 0.9 per cent. This figure is however made up of a variety of increases and decreases in different countries (see table 5). While military spending fell in Oceania (chiefly Australia), it increased in Central and South Asia and in East Asia, although the latter increase was almost entirely due to China.

In particular, military expenditure in South East Asia rose by 5.0 per cent, led by increases in Indonesia, the Philippines and Viet Nam, the latter two prompted to a significant extent by tensions with China over territorial disputes in the South China Sea.
Table 5. Military expenditure in Asia and Oceania

\begin{tabular}{lccl} 
& \multirow{2}{*}{\begin{tabular}{l} 
Spending, \\
\cline { 3 - 4 }
\end{tabular}} & \multicolumn{2}{l}{ Change (\%) } \\
\cline { 3 - 4 } & $2013($ b.) & $2012-13$ & $2004-13$ \\
\hline Asia and Oceania & 407 & 3.6 & 62 \\
Central and South & 63.7 & 1.2 & 49 \\
$\quad$ Asia & & & \\
East Asia & 282 & 4.7 & 74 \\
Oceania & 25.9 & -3.2 & 19 \\
South East Asia & 35.9 & 5.0 & 47 \\
\hline
\end{tabular}

Major changes, 2012-13

\begin{tabular}{lcll}
\hline Major increases & $\%$ & Major decreases & $\%$ \\
\hline Afghanistan & 77 & Timor-Leste & -12 \\
Philippines & 17 & Australia & -3.6 \\
Sri Lanka & 12 & Taiwan & -2.6 \\
Kazakhstan & 10 & & \\
\hline
\end{tabular}

\section{The Middle East}

Military expenditure in the Middle East increased by 4 per cent in real terms in 2013 and 56 per cent between 2004 and 2013, to reach an estimated $\$ 150$ billion (see table 6). While figures for military expenditure in the Middle East have traditionally been very uncertain, the lack of data has worsened recently. In 2013, there was no available data for Iran, Qatar, Syria, the United Arab Emirates and Yemen.

The largest increases in military spending were in Iraq (27 per cent) and Bahrain (26 per cent). It is likely that increases in defence spending in Bahrain are related to recent purchases of arms used to suppress domestic unrest as well as to troubled relations with neighbouring Iran. In Iraq, recent increases are aimed at building the capacity and armaments of the Iraqi armed forces, in order to improve the security of citizens, access to services and protection of oil production and exports.

Saudi Arabia, the largest spender in the region, increased spending by 14 per cent to a total of $\$ 67.0$ billion in 2013 .

In Oman, in contrast, military expenditure fell by 27 per cent compared to 2012, but it was still 31 per cent higher than in 2011. This is the result of large supplementary budgets in both 2012 and 2013, representing a 'one-off major increase for equipment modernization and staff expansion'. Oman has the largest military burden in the Middle East, at 11.3 per cent of GDP in 2013.

Table 6. Military expenditure in the Middle East

\begin{tabular}{llll} 
& Spending, & \multicolumn{2}{l}{ Change (\%) } \\
\cline { 3 - 4 } & $2013($ b.) & $2012-13$ & $2004-13$ \\
\hline Middle East & $(150)$ & 4.0 & 56 \\
\hline
\end{tabular}

Major changes, 2012-13

\begin{tabular}{llll}
\hline Major increases & $\%$ & Major decreases & $\%$ \\
\hline Iraq & 27 & Oman & -27 \\
Bahrain & 26 & Yemen & -12 \\
Saudi Arabia & 14 & Jordan & -9.4 \\
\hline
\end{tabular}

() = uncertain estimate.

\section{THE BIGGEST INCREASES IN MILITARY SPENDING, 2004-13}

A total of 23 countries have doubled their military spending in real terms since 2004 (excluding countries that spent less than $\$ 100$ million in 2013see figure 4). What is striking about these countries is their diversity and the variety of reasons behind their increases, where a reason can be discerned. The countries are in all regions and subregions apart from North America, Western and Central Europe, and Oceania. 


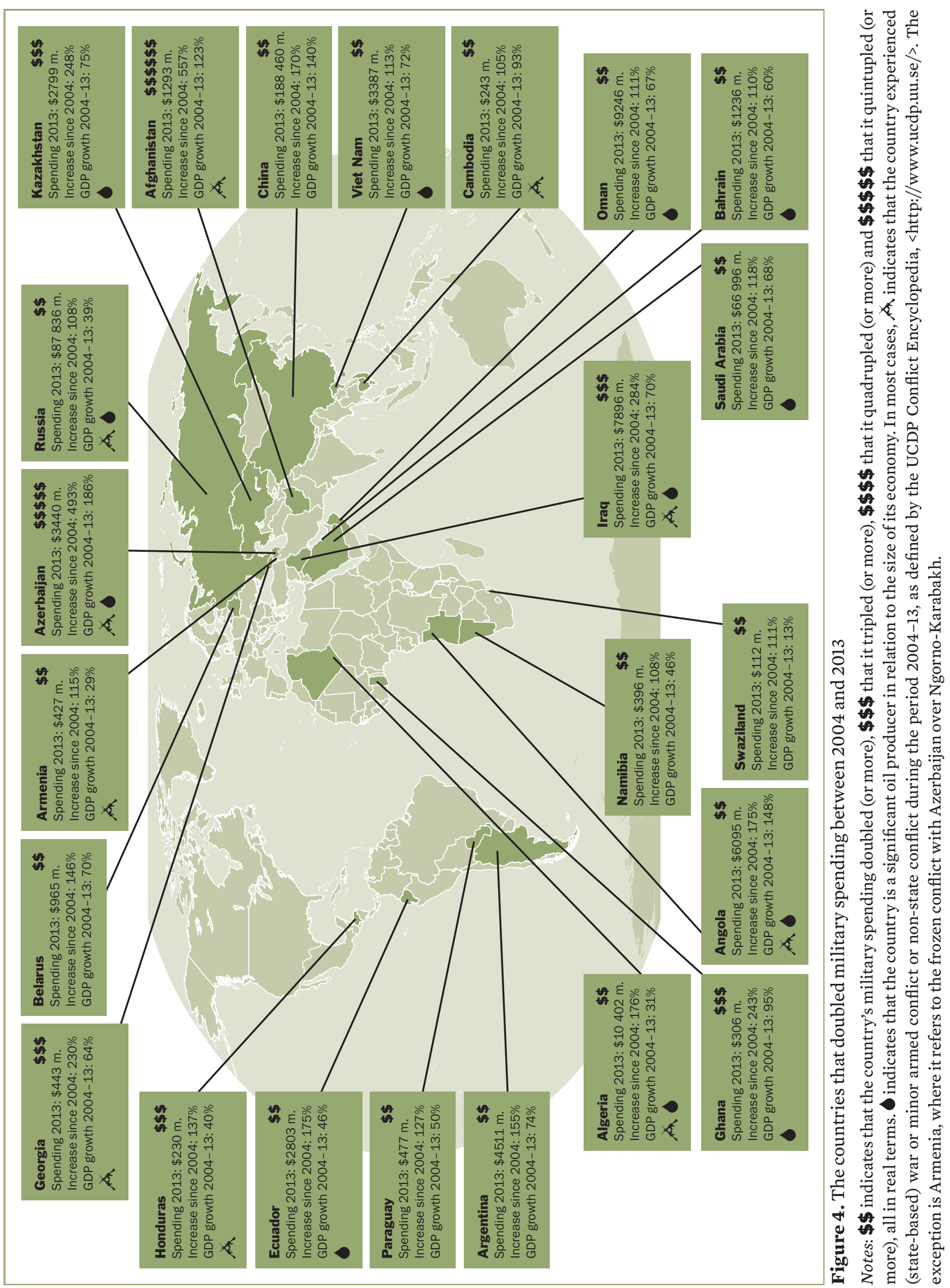


Nearly all of the 23 countries display at least one of three characteristics:

- very strong economic growth,

- high oil or gas revenues, or

- significant armed conflict or other violence.

In all cases, growth of military spending over the period was higher than growth in GDP (both in real terms). Economic growth is a clear driver in some cases, such as China and Angola, but others countries have increased military spending on the basis of much weaker growth records.

A factor common to many of the countries is a high level of revenue from oil and gas exportsin some cases, such as Ghana, recently discovered or exploited. This resource provides a ready source of income for the state that does not require taxing the general population. However, the presence of such natural resouces can generate new security concerns, either internal or external. Poor governance of the revenues from natural resources may also be a factor that tends to favour the diversion of those revenues to military uses.

Many of the 23 countries have experienced armed conflict over the period or dangerous ongoing frozen conflicts, such as that between Armenia and Azerbaijan. The most striking example of a large rise in military expenditure is Afghanistan (see box 1). While there is no state-based armed conflict in the case of Honduras, the homicide rate there is among the highest in the world. However, some of the countries, such as Ecuador, Kazakhstan, Namibia, Paraguay and Swaziland, enjoy essentially peaceful security environments.
Box 1. Military spending in Afghanistan and the withdrawal of ISAF

Not only did Afghanistan have the world's highest increase in military expenditure in 2013, at 77 per cent, spending had risen by 557 per cent over the decade since 2004. This huge increase is the result of Afghanistan's efforts to build its defence and security forces from scratch, heavily supported by foreign aid. The particularly large increase in 2013 is the result of an increase in salaries and wages for the Afghan National Army, which reached its target goal of 195000 ldiers in 2012, and as a result of preparations for the departure of foreign forces at the end of 2014.

ore than a decade of operations in Afghanistan, personnel will be responsible for the state's security. Some other counwill continue to support the Afghan national security forces, but they will not have a combat role. 
SIPRI is an independent international institute dedicated to research into conflict, armaments, arms control and disarmament. Established in 1966, SIPRI provides data, analysis and recommendations, based on open sources, to policymakers, researchers, media and the interested public.

\section{GOVERNING BOARD}

Göran Lennmarker, Chairman (Sweden)

Dr Dewi Fortuna Anwar (Indonesia)

Dr Vladimir Baranovsky (Russia)

Ambassador Lakhdar Brahimi (Algeria)

Jayantha Dhanapala (Sri Lanka)

Ambassador Wolfgang Ischinger (Germany)

Professor Mary Kaldor (United Kingdom)

The Director

\section{DIRECTOR}

Professor Tilman Brück (Germany)

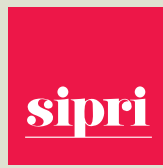

STOCKHOLM INTERNATIONAL PEACE RESEARCH INSTITUTE Signalistgatan 9 SE-169 70 Solna, Sweden Telephone: +4686559700 Fax: +4686559733

Email:sipri@sipri.org Internet: www.sipri.org

\section{THE SIPRI MILITARY EXPENDITURE DATABASE}

The SIPRI Military Expenditure Database provides military expenditure data by country for the years 1988-2013

- in local currency, at current prices,

- in US dollars, at constant (2012) prices and exchange rates, and

- as a share (\%) of gross domestic product (GDP).

SIPRI military expenditure data is based on open sources only, including a SIPRI questionnaire that is sent out annually to governments. The collected data is processed to achieve consistent time series which are, as far as possible, in accordance with the SIPRI definition of military expenditure.

The database is available at $\langle\mathrm{http}: / / \mathrm{ww} w$.sipri.org/databases/milex/ $>$.

\section{The definition of military expenditure}

Where possible, SIPRI military expenditure data includes all current and capital expenditure on

- the armed forces, including peacekeeping forces,

- defence ministries and other government agencies engaged in defence projects,

- paramilitary forces, when judged to be trained and equipped for military operations, and

- military space activities.

Such expenditure should include

- military and civil personnel, including retirement pensions of military personnel and social services for personnel,

- operations and maintenance,

- procurement,

- military research and development, and

- military aid (in the military expenditure of the donor country).

Civil defence and current expenditure on previous military activities-such as veterans' benefits, demobilization, conversion and weapon destructionare excluded.

\section{ABOUT THE AUTHORS}

Dr Sam Perlo-Freeman (United Kingdom) is Director of the SIPRI Military Expenditure Programme.

Carina Solmirano (Argentina) is a Senior Researcher with the SIPRI Military Expenditure Programme. 